\title{
Community Based Tourism Tantangan Dusun Nglepen dalam Pengembangan Desa Wisata
}

\author{
Dhimas Setyo Nugroho \\ Akpar BSI Yogyakarta, dhimas42@gmail.com
}

\begin{abstract}
ABSTRAK
Masyarakat Dusun Nglepen pada awalnya adalah masyarakat pedesaan yang mayoritas menggantungkan mata pencaharian sebagai petani. Setelah bencana gempa bumi 5,9 skala richter yang menimbulkan kerusakan parah pada Sabtu 27 Mei 2006, Dusun Nglepen direlokasi ke wilayah lain, dibangun dengan bangunan rumah tahan gempa berbentuk kubah (dome). Keunikan desain rumah dome justru menjadi daya tarik desa wisata yang sangat diminati. Disisi lain, peralihan sosio-kultural masyarakat Dusun Nglepen menjadi masyarakat pariwisata sangat menarik untuk diamati. Artikel ini menyajikan gambaran tantangan dalam pengembangan Community Based Tourism Dusun Nglepen yang dikaji berdasarkan teori partisipasi masyarakat melalui analisis deskriptif kualitatif. Hasil menunjukan bahwa semakin tinggi partisipasi warga, maka semakin tinggi dampaknya tehadap masyarakat. Dampak yang ditemukan cenderung bernilai positif bagi masyarkat baik secara ekonomi maupun sosial budaya. Selanjutnya dampak positif yang dirasakan masyarakat cenderung mempengaruhi tingkat partisipasi dalam pengembangan pariwisata.
\end{abstract}

Kata kunci : Community-Based Tourism, Desa Wisata, Partisipasi Masyarakat

\begin{abstract}
In the beginning, the community of the village dwellers that worked as a farmer. After the disastrous earthquake of a 5.9 magnitude earthquake that caused severe damage on Saturday, May 27, 2006, the village relocated to other areas, houses constructed with earthquake resistant with the shape of a dome (dome). The uniqueness of the design of the House, thus becoming an attraction. On the other hand, the transition of social-cultural into tourism community is very interesting to observe. This article presents an overview of the challenges in the development of community-based tourism, based on the theory of community participation through a descriptive qualitative analysis. The results showed that the higher the participation of citizens, then the higher the impact on the community. The impact positive for society, both economically, socially and culturally. In addition, the positive impact affected the level of community participation in tourism development. Key words : Community-Based Tourism, Tourism Village, Community Participation
\end{abstract}

Naskah Masuk : 5 Maret 2018

Naskah Direvisi : 6 Maret 2018

Naskah Diterima : 6 April 2018

ISSN: 2355-6587, e-ISSN: 2528-2220

http://ejournal.bsi.ac.id/ejurnal/index.php/jp 


\section{PENDAHULUAN}

Sebagian wilayah di Daerah Istimewa Yogyakarta merupakan kawasan rawan bencana, khususnya gempa bumi. Selain ancaman gempa tektonik, ancaman gempa dari letusan gunung Merapi juga merupakan potensi bencana yang sering mengancam beberapa daerah khususnya di wilayah Yogyakarta bagian utara. Data Badan Penganggulangan Bencana Daerah (BAPAKBD) Yogyakarta yang dikutip Muktaf (2017), menyebutkan bahwa Yogyakarta pernah mengalami gempa tektonik sebanyak 7 kali dari rentang tahun 1867 sampai tahun 2006. Gempa terbesar yakni tahun 1867, 1943 dan 2006.

Gempa terakhir yang cukup dasyat terjadi pada tanggal 27 Mei 2006 merenggut sebanyak 5.737 korban dengan rincian 4.674 di DIY dan 1.063 di Jawa Tengah. Sebanyak 38.423 orang luka berat dan ringan di kedua provinsi itu. Dampak gempa mengakibatkan tidak kurang dari 570.490 rumah rusak baik itu ringan ataupun hancur.

Salah satu wilayah yang terdampak bencana gempa cukup dasyat pada waktu itu adalah jogja bagian timur, tepatnya di Dusun Nglepen Desa Sumberharjo, Kecamatan Prambanan, Kabupaten Sleman, Daerah Istimewa Yogyakarta (DIY). Secara geologis, Dusun Nglepen terletak di perbukitan yang dilalui patahan, atau sesar Opak-Oya. Sehingga, dampak gempa 2006 pada saat itu menjadi sangat besar, dusun itu hancur, rumah-rumah penduduk rata dengan tanah. Bahkan tanah di dusun amblas sedalam 7 meter (Ayuningtyas, 2016).

Pasca bencana gempa bumi, dibangunlah 80 bangunan Dome berbentuk setengah lingkaran untuk merelokasi Dusun Nglepen oleh Domes for The World dari Texas, Amerika Serikat (AS) yang bekerjasama dengan World Association of the

$$
\text { Non-Government }
$$

Organization dan Emaar Properties Dubai (Martono, 2013).

Namun disisi internal, pengembangan rumah dome masih kontroversional. Rumah dome dinilai tidak mengindahkan lokalitas, dalam hal ini rumah yang sesuai dengan sosio-kultural masyarakat Jawa di pedesaan (Saraswati, 2008). Padahal desain perumahan seharusnya mampu merefleksikan way of life masyarakatnya (Farmer, 1993).

Masyarakat Nglepen pada awalnya adalah masyarakat pedesaan yang mayoritas menggantungkan mata pencaharian sebagai petani dan memelihara ternak. Saat ini tinggal di rumah dome tidak bisa memelihara hewan ternak, tentu terdapat perubahan pola kehidupan sosio-kultural yang yang sangat terasa bagi masyarakat.

Disisi lain rumah-rumah dome yang berbentuk kubah setengah lingkaran ternyata menjadi daya tarik tersendiri di Dusun Nglepen. Semakin hari semakin banyak dikunjungi wisatawan. Wisatawan sangat menikmati keunikan rumah dome, yang dianggap mirip dengan rumah teletubies, tokoh fiksi lucu dalam serial anak. Dalam konsep pariwisata, dimana ada keunikan disitu akan semakin menarik hingga memuaskan wisatawan dalam berwisata (Hermawan, 2017a).

Seiring banyaknya minat berkunjung wisatawan untuk melihat keunikan rumah dome, para tokoh masyarakat menginisiasi untuk pengembangan Desa Wisata Rumah Dome (Sulasmono). Perjalanan pengembangan rumah dome tentu tidaklah mudah, apalagi pengembangan desa wisata yang harus melibatkan partisipasi masyarkat lokal melalui konsep pariwisata berbasis masyarakat, atau dikenal sebagai Community Based Tourism (CBT).

Oleh karena itu, artikel ini akan mengkaji pengembangan Community Based Tourism Dusun Nglepen yang dikaji berdasarkan teori partisipasi masyarakat melalui analisis diskriptif kualitatif

\section{KAJIAN LITERATUR \\ Desa Wisata}

Menurut Pitana (2009), destinasi adalah tempat yang dikunjungi dengan waktu yang signifikan selama perjalanan seseorang dibandingkan dengan tempat lain yang dilalui selama perjalanan (misalnya daerah transit).

Sedangkan desa wisata dimaknai sebagai suatu bentuk integrasi antara atraksi wisata, akomodasi dan fasilitas pendukung yang disajikan dalam suatu struktur 
kehidupan masyarakat yang menyatu dengan tata cara dan tradisi yang berlaku (Nuryanti, 1993) dan (Victoria br. Simanungkalit, Destry Anna Sari, Frans Teguh, Hari Ristanto, Ika K, Leonardo Sambodo, Samsul Widodo, Masyhud, Sri Wahyuni, Henky Hermantoro, Henky Hermantoro, 2015).

Sehingga dapat disimpulkan kembali bahwa desa wisata merupakan sebuah destinasi wisata yang berbasis kehidupan pedesan dengan daya tarik berupa alam, maupun kehidupan sosial dan budaya masyarakat, yang didukung saranaprasarana wisata lokal oleh masyarakatnya.

\section{Community-based Tourism}

Pengembangan desa wisata sangat dianjurkan untuk mengaplikasikan konsep Community Based Tourism (CBT) sebagai fundamental pembangunanya.

CBT ditujukan sebagai alat pengembangan komunitas serta konservasi lingkungan. Untuk tujuan ini, harus dilihat secara menyeluruh mengenai aspek yang dapat memberikan dampak pada komunitas seperti aspek sosial, budaya, ekonomi, lingkungan dan politik.

Semua itu dimiliki oleh masyarakat, dikelola oleh masyarakat, serta dinikmati untuk masyarakat ("Kyrgyz Community Based Tourism," 2017); (Hermawan, 2016).

Pengembangan CBT ditujuan untuk meningkatkan kesadaran pengunjung dan belajar mengenai bagaimana cara hidup komunitas (Suansri, Yeejaw-haw, \& Richards, 2013)

Pengembangan Community Based Tourism membutuhkan partisipasi masyarakat yang baik, dalam konsep pariwisata berbasis masyarakat, masyarakat seharusnya diajari untuk mengelola destinasi pariwisata agar tercapai pariwisata yang berkelanjutan (Sunaryo, 2013).

\section{Partisipasi Masyarakat}

Partisipasi masyarakat adalah keikutsertaan, keterlibatan, dan kesamaan anggota masyarakat dalam suatu kegiatan tertentu baik secara langsung maupu tidak langsung, sejak dari gagasan perumusan kebijakan, pelaksanaan program dan evaluasi (Rubiantoro dan Haryanto, 2013).
Dengan adanya partisipasi masyarakat, pengembangan desa wisata cenderung membawa dampak yang positif bagi masyarakat lokal (Hermawan, 2016a).

Arnstein (1969) menggambarkan partisipasi masyarakat sebagai suatu pola bertingkat (ladder patern) yang tediri dari 8 tingkat, dimana tingkatan paling bawah merupakan tingkat partisipasi masyarakat sangat rendah, menengah, kemudian tingkat yang paling atas merupakan tingkat dimana partisipasi masyarakat sudah sangat besar dan kuat.

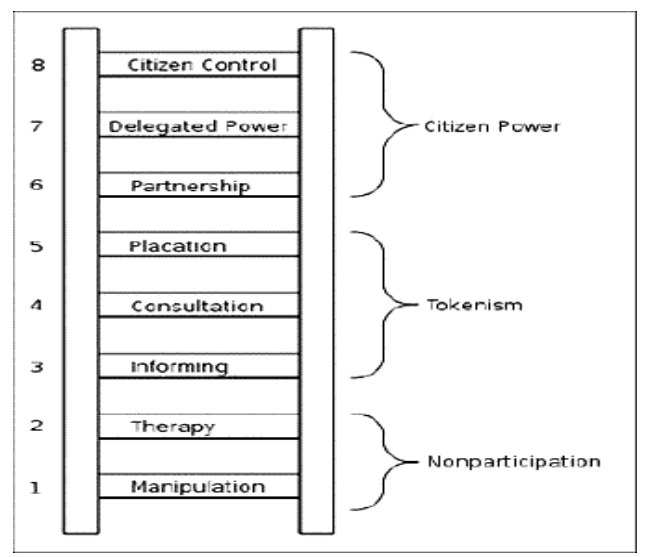

Gambar 1. Tangga partisipasi menurut Arnstein (1969)

Bagian pertama Nonparticipan (tidak ada partisipasi), dari Manipulation dan Therapy. Pada bagian ini, inisiator atau otoritas yang berkuasa sengaja menghapus segala bentuk partisipasi publik. Pada tingkat Manipulation, mereka memilih dan mendidik sejumlah orang sebagai wakil dari publik. Fungsinya, ketika mereka mengajukan berbagai program, maka para wakil publik tadi harus selau menyetujuinya. Sedangkan publik tidak diberitahu tentang hal tersebut. Pada tingkat Therapy, inisiator sedikit memberitahu kepada publik tentang beberapa programnya yang sudah disetujui oleh wakil publik. Publik hanya bisa mendengarkan saja.

Bagian kedua, Tokenism (delusif) dengan rentang dari Informing, Consultation dan Placation. Dalam Tokenism, otoritas yang berkuasa menciptakan citra, tidak lagi menghalangi partisipasi publik. Akan tetapi kenyataan yang terjadi berbeda, benar partisipasi publik dibiarkan, namun 
mereka mengabaikannya dan mereka tetap mengeksekusi rencananya semula. Ketika berada di tingkat Informing, inisiator program menginformasikan macammacam program yang akan dan sudah dilaksanakan namun hanya dikomunikasikan searah, dan publik belum dapat melakukan komunikasi umpan-balik secara langsung. Untuk tingkat Consultation, inisiator berdiskusi dengan banyak elemen publik tentang berbagai agenda. Semua saran dan kritik didengarkan tetapi mereka yang mempunyai kuasa memutuskan, apakah saran dan kritik dari publik dipakai atau tidak. Pada tingkat Placation, inisiator berjanji melakukan berbagai saran dan kritik dari publik, namun mereka diamdiam menjalankan rencananya semula.

Partnership, Delegated Power dan Citizen Control merupakan jajaran tingkatan di bagian ketiga, yaitu Citizen Power (publik berdaya). Saat partisipasi publik telah mencapai CitizenPower, maka otoritas yang berkuasa sedang benar-benar mendahulukan peran publik dalam berbagai hal. Saat berada pada tingkat Partnership, mereka memperlakukan publik selayaknya rekan kerja. Mereka bermitra dalam merancang dan mengimplementasi aneka kebijakan publik. Naik ke tingkat Delegated Power, mereka mendelegasikan beberapa kewenangan kepada publik. Contoh, publik punya hak veto dalam proses pengambilan keputusan. Tingkat tertinggi yaitu Citizen Control. Pada tingkatan ini publik lebih mendominasi ketimbang mereka (otoritas), bahkan sampai dengan mengevaluasi kinerja mereka. Partisipasi publik yang ideal tercipta di tingkat ini.

\section{METODE PENELITIAN}

Pendekatan kualitatif digunakan untuk memperoeh gambaran diskriptif yang lebih luas mengenai fenomena yang diamatai (Moleong, 1995; Hermawan, 2017b; 2017). Karena, pendekatan kualitatif dipandang mampu menggali pemaknaan terhadap fenomena secara lebih mendalam (Creswell, 1994). Fenomena yang dimaksud mengenai peluang dan tantangan dalam mewujudkan Community Based
Tourism Desa Wisata Nglepen (Rumah Dome) sebagai solusi dalam pembangunan Dusun Nglepen.

Pengumpulan data dilakukan dengan teknik observasi langsung, dokumentasi dan studi pustaka. Didukung dengan data hasil wawancara kepada narasumber. Adapun pihak-pihak yang menjadi keyperson meliputi: 1) Kepala Dusun Nglepen; 2) Bapak Sulasmono selaku Pengurus Desa Wisata Rumah Dome; 3) Ibu Suginem selaku perwakilan masyarakat lokal.

Triangulasi digunakan untuk mencapai tingkat kevalidan data sehingga layak untuk interprestasi dan pemaknaan hasil riset. Triangulasi waktu telah dilakukan sejak 22/08/2016 hingga 28/07/2017 pada proses observasi hingga verifikasi. Triangulasi teknik dilakukan dengan wawancara kepada para informan kunci, melakukan observasi, serta dokumentasi. Triangulasi sumber dengan cara mewawancarai para informan kunci satu dengan yang lain, lalu mencocokan jawaban para informan kepada warga menggunakan angket dan wawancara (Sugiyono, 2011).

\section{PEMBAHASAN}

\section{Gambaran Umum Dusun Nglepen Baru} (Desa Wisata Rumah Dome)

Daya tarik wisata desa wisata Rumah Dome adalah bangunan komplek rumah yang berbentuk setengah bola yang dulu berwarna putih, akan tetapi saat ini komplek perumahan tersebut memiliki bermacam-macam warna. Desa wisata rumah dome menawarkan beberapa paket wisata seperti treking, bersepeda, sawahan, gerobak sapi beserta paket makannya. Desa wisata rumah dome memiliki agenda tahunan yaitu merti dusun. Acara merti dusun ini adalah agenda tahunan yang melibatkan seluruh warga komplek rumah dome.

Saat ini, desa wisata rumah dome sedang mengembangkan daya tarik wisata baru, berupa Bukit Teletabis. Bukit Teletabis sendiri berada di puncak gunung yang berjarak kurang dari $1 \mathrm{~km}$ dengan desa wisata rumah dome. Bukit Teletabis adalah bukit yang dapat digunakan sebagai gardu 
pandang selebar kurang lebih 5 meter untuk melihat pemandangan dari ketinggian. Dilengkapi dengan taman bunga, lalu fasilitas umum seperti toilet, mushola dan tempat parkir. Dari Bukit Teletabis, wisatawan dapat melihat pemandangan komplek rumah dome, dan pemandangan matahari terbenam / sunset.

\section{Gambaran Pengelolaan Rumah Dome}

Desa wisata Rumah Dome (Dusun Nglepen) telah berbadan hukum sebagai Badan Usaha Milik Desa (BUMDes) berdiri diatas tanah kas desa Sumberharjo dengan luas $2.3350 \mathrm{Ha}$. Warga sebenarnya tidak memiliki hak atas kepemilikan tanah, warga hanya memiliki hak guna bangunan. Setiap tahunnya, warga dikenakan biaya sewa tanah kepada kelurahan Sumberharjo. Desa wisata Rumah Dome berupa komplek perumahan yang berbentuk setengah bola, dengan jumlah 80 unit bangunan dome. 71 unit bangunan dome adalah rumah warga, terbagi menjadi 6 blok A, B, C, D, E dan F. Sisanya adalah bangunan fasilitas umum, 6 unit MCK komunal yang tersebar di setiap blok, 1 unit mushola, 1 unit aula dan 1 unit POSKESDES. Desa wisata ini terdiri dari RT 02 dan RT 06. Mayoritasnya warganya adalah petani.

Wisata Rumah Dome ini dikelola oleh pengelola rumah dome. Organisasi ini adalah organisasi yang dibentuk atas kesepakatan warga, dan memiliki SK resmi dari kelurahan desa Sumberharjo.

Struktur organisasi tersebut terdiri dari pelindung yaitu Kepala desa Sumberharjo, penasehat yaitu Kepala dusun Sengir, ketua dan wakil, sekertaris 1 dan 2, bendahara 1, 2 dan 3, POKDARWIS, seksi kebersihan, seksi keamanan, seksi LINMAS, seksi pembangunan.

Dalam pengelolaanya, wisatawan rumah dome diwajibkan membayar tiket masuk sebesar Rp 5.000/per-orang dan biaya parkir motor sebesar Rp 2.000/per-motor. Serta mengisi buku tamu di sekertariat Pokdarwis.

Pengelolaan Partisipasi Masyarakat dalam pengelolaan Desa Wisata Rumah Dome

Arnstein (1969) menggambarkan partisipasi masyarakat sebagai suatu pola bertingkat (ladder patern) yang tediri dari
8 tingkat, dimana tingkatan paling bawah merupakan tingkat partisipasi masyarakat sangat rendah, menengah, kemudian tingkat yang paling atas merupakan tingkat dimana partisipasi masyarakat sudah sangat besar dan kuat.

\section{Tahap Non Partisipasi}

Bagian pertama merupakan Nonparticipan (tidak ada partisipasi) berjenjang dari Manipulation dan Therapy. Pada bagian ini, pihak yang berwenang sengaja menghapus segala bentuk partisipasi masyarakat.

\section{Manipulasi}

Manipulasi adalah tahap dimana pihak yang berwenang memilih dan mendidik sejumlah orang sebagai wakil dari warga. Fungsinya, ketika pihak yang berwenang mengajukan berbagai program, maka para wakil warga tadi harus selalu menyetujuinya. Sedangkan warga tidak diberitahu tentang hal tersebut. Dalam kasus desa wisata rumah dome, tahap manipulasi terjadi pada saat warga mulai membentuk organisasi karena banyaknya kunjungan tamu yang datang. Pada awalnya pemerintah desa beserta pamong membentuk 2 RT di komplek rumah dome. RT 02 diketuai oleh Bapak Sakiran dan RT 06 diketuai oleh Bapak Sugiyono. Banyaknya tamu yang berkunjung, memicu inisiatif warga dengan mencoba mengelola retribusi parkir. Pengurus yang dipilih pun bukan berdasarkan pemilihan, akan tetapi hanya penunjukkan secara mufakat oleh beberapa warga. Pada awal pemilihan pengurus, Bapak Sugiyono dan Bapak Sakiran dipilih secara mufakat oleh beberapa orang, karena mereka berdua adalah selaku ketua RT pada waktu itu.

\section{Terapi}

Terapi adalah tahap dimana pihak yang berwenang sedikit memberitahu kepada warga tentang beberapa programnya yang sudah disetujui oleh wakil warga / pengurus yang ditunjuk, sehingga warga hanya bisa mendengarkan saja. Dalam kasus desa wisata rumah dome. Tahap terapi terjadi ketika awal organisasi yang mengelola kunjungan tamu terbentuk. Bapak Sugiyono dan Bapak Sakiran selaku ketua yang pertama menangani semua sendirian. Mulai dari mengurus datangnya 
kunjungan tamu, hingga mengurus hal ke dinas pariwisata. Setelah itu, beliau menyampaikan segala informasi yang diperoleh dari dinas pariwisata kepada warga.

\section{Tahap Tokenism}

Dalam Tokenism, pihak yang berwenang menciptakan citra, tidak lagi menghalangi partisipasi masyarakat. Namun kenyataan berbeda, benar partisipasi masyarakat dibiarkan, namun mereka mengabaikannya dan mereka tetap mengeksekusi rencananya semula.

\section{Menyampaikan Informasi}

Dalam tahap ini, pihak yang berwenang menginformasikan macam-macam program yang akan dan sudah dilaksanakan namun hanya dikomunikasikan searah. Warga belum dapat melakukan komunikasi umpan-balik secara langsung. Dalam kasus desa wisata rumah dome, tahap penyampaian infromasi ini terjadi ketika awal komplek rumah dome berubah menjadi desa wisata. Agar warga mendapat pengetahuan tentang desa wisata, pada awalnya warga dianjurkan studi banding ke Pentingsari oleh kepala desa yang pada waktu itu menjabat. Tetapi hanya beberapa warga yang mengikuti studi banding.

\section{Konsultasi}

Pihak yang berwenang berdiskusi dengan banyak elemen warga tentang berbagai agenda. Semua saran dan kritik didengarkan tetapi mereka yang mempunyai kuasa memutuskan, apakah saran dan kritik dari warga dipakai atau tidak. Dalam tahap ini, setelah warga pindah di komplek rumah dome, warga secara rutin mulai mengadakan pertemuan setiap 3 bulan sekali. Untuk membahas segala sesuatu yang terjadi, seperti membuat aturan di komplek rumah dome dengan warga. Akan tetapi karena membaiknya tata kelola kepengurusan, pertemuan diadakan sewaktu-waktu tergantung tingkat kepentingan dengan melihat kondisi dan situasi. Pengelola dan warga pernah mengadakan rapat untuk membahas aturan yang akan disepakati bersama di komplek rumah dome. Setelah itu, aturan tersebut dibuat menjadi sebuah berita acara dengan lampiran aturan dan disebarkan warga.

Pengelola sempat berselisih dengan warga karena rumah domenya dihuni oleh rekannya. Warga yang tidak terima dengan hal tersebut, memaki-maki pengelola rumah dome. Tapi pada akhirnya pengelola berhasil meredam warga yang marah dan memberi penjelasan kepada warga tersebut. Selain itu pengelola pernah berselisih dengan warga luar komplek rumah dome, karena ditolak perijinannya untuk menyewa salah satu rumah dome yang kosong. Selain itu, penyewaan lapangan adalah hasil dari usulan Pokdarwis untuk menunjang kegiatan wisata. Pada awalnya pengelola ragu jika diminta menyewa lapangan, karena akan menambah biaya sewa. Akan tetapi setelah berdiskusi dan meminta saran dari banyak pihak, akhirnya pengelola menyewa lapangan tersebut.

\section{Peredaman Kemarahan}

Peredaman kemarahan adalah tahap dimana pihak yang berwenang berjanji melakukan berbagai saran dan kritik dari warga. Namun mereka diam-diam menjalankan rencananya semula.

Dalam kasus desa wisata rumah dome, pengelola pernah menampung kritikan dari waga mengenai beberapa aturan yang ditetapkan. Agar aturan yang ditetapkan dapat berjalan lancar dan kritik warga juga ditampung. Maka pengelola mengambil jalan tengah, yaitu tetap menjalankan aturan pokok dengan memberikan sedikit toleransi dalam aturan tersebut. Salah satu contohnya adalah, untuk memenuhi syarat cairnya dana pengembangan bukit teletabis. Dinas pekerjaan umum (PU) meminta agar warga menebang semua pohon lebih tinggi dari rumah dome. Pengelola pun mau tidak mau harus melakukan hal tersebut. Akan tetapi untuk mengurangi panas akibat tidak adanya pohon yang tinggi, pengelola mengijinkan warga untuk menanam pohon yang ketinggiannya $2 / 3$ dari rumah dome.

Selain itu terdapat kesepakatan bahwa, pengelola tidak mengijinkan warga untuk menyimpan jerami diluar rumah, untuk menjaga kebersihan. Akan tetapi pengelola memberikan toleransi bahwa, 
diperbolehkan mengeringkan jerami dengan syarat jika sudah selesai, jeramijerami tersebut harus dimasukkan ke dalam rumah.

\section{Tahap Kekuasaan Masyarakat (Citizen Control)}

Tingkat tertinggi yaitu Citizen Control. Masyarakat yang lebih mendominasi ketimbang pihak yang berwenang. Bahkan sampai dengan mengevaluasi kinerja mereka. Partisipasi masyarakat yang ideal tercipta di tingkat ini.

\section{Kemitraan}

Kemitraan adalah tahap dimana pihak yang berwenang memperlakukan warga selayaknya rekan kerja.

Pengurus bermitra dalam merancang dan mengimplementasi aneka kebijakan warga. Dalam kasus desa wisata rumah dome, pengelola bersama warga menyusun aturan penggunaan fungsi bangunan fasilitas umum di desa wisata rumah dome. Rumah dome tidak dapat menampung warga apabila mereka mengadakan pertemuan. Sehingga warga dan pengelola sepakat menggunakan aula sebagai tempat bermusyawarah jika hujan. Jika tidak hujan, warga melakukan musyawarah di jalan. Selain itu demi menambah pendapatan bagi desa wisata. Warga menyepakati kebijakan bahwa rumah dome yang tidak dihuni akan difungsikan sebagai homestay dan galeri wisata. Sehingga dapat menunjang kegiatan wisata dan meningkatkan pendapatan warga. Untuk status kepemilikan hak bangunan tetap milik warga.

Dalam kaitan perijinan kegiatan wisata, Pokdarwis sudah merancang aturan bagi wisatawan yang akan menginap atau melakukan kegiatan wisata di desa wisata rumah dome. Pengelola dan warga akan saling koordinasi mengenai perijinan detil info wisatawan, jenis kegiatan, waktu kegiatan dan daerah mana saja yang akan dilalui selama kegiatan tersebut berlangsung.

Untuk saat ini, warga sedang fokus dalam membahas badan hukum dan sistem bagi hasil Bukit Teletabis. Serta mereka membahas sedikit rancangan aturan yang akan ditetapkan di bukit teletabis. Lahan yang akan dijadikan sebagai bukit teletabis adalah lahan milik perorangan. Pengelola rumah dome berdiskusi dengan pemilik lahan bukit teletabis mengenai bagi hasil pendapatan dari bukit teletabis untuk mencapai kesepakatan yang adil bagi kedua belah pihak antara pihak desa wisata rumah dome dan pemilik lahan (Mbah Marmo). Selain itu, pengelola rumah dome dan seluruh tokoh dusun akan bermusyawarah dengan kepala desa mengenai badan hukum Bukit Teletabis apakah akan menjadi BUMDes atau memakai akta notaris. Saat ini warga sedang merencanakan mengenai petugas pengelola harian bukit teletabis adalah gabungan antara warga komplek rumah dome dan warga sekitar bukit teletabis.

\section{Pendelegasian Kekuasaan}

Pengelola mendelegasikan beberapa kewenangannya kepada warga. Dalam hal kepengurusan rumah dome, pengurus memberikan beberapa kewenangannya kepada warga dengan cara membentuk seksi-seksi dalam kepengurusan. Beberapa seksi yang terbentuk adalah seksi Pokdarwis, LINMAS, keamanan dan kebersihan. Pengelola bahkan melibatkan orang dari luar komplek dome, asalkan mereka memiliki komitmen tinggi untuk berkontribusi kemajuan di desa wisata rumah dome. Akan tetapi pengelola tetap memprioritaskan warga rumah dome menjadi pengurus. Warga komplek rumah dome juga tidak keberatan dengan hal tersebut.

Selain itu, Pokdarwis ditunjuk sebagai petugas pelaksana harian kegiatan wisata di desa wisata rumah dome. Sehingga pengelola rumah dome tidak menangani pengelolaan pariwisata secara langsung. Jadi apabila Pokdarwis mengadakan kegiatan wisata seperti paket-paket wisata, dapat langsung dilaksanakan tanpa harus meminta ijin dari pengelola rumah dome. Pengelola juga mendelegasikan tugas penyelenggaraan merti dusun kepada masyarakat dengan membentuk panitia baru. Sehingga pengelola tidak terlibat secara langsung sehingga pengelola menjabat sebagai penanggung jawab dan penasehat. Pengelola memberikan wewenang kepada UKM. Kaitannya dengan penyediaan makanan untuk 
kegiatan wisata, ataupun untuk kegiatan internal di desa wisata rumah dome seperti gotong royong dan pertemuan warga.

\section{Pengawasan Masyarakat}

Warga yang lebih mendominasi ketimbang pengurus selaku otoritas, bahkan sampai dengan mengevaluasi kinerja mereka. Partisipasi warga yang ideal tercipta di tingkat ini. Dalam kasus desa wisata rumah dome, sejak awal dibentuknya organisasi. Pengelola memang sudah berinisiatif untuk melaporkan hasil keuangan kepada warga, sehingga tidak menimbulkan salah paham mengenai kunjungan tamu dan kaitannya dengan jumlah uang yang masuk. Selain itu, mengenai pemasukan keuangan perhari. Pokdarwis mencatat semua pemasukan dan pengeluaran perhari sebagai bentuk tanggung jawab dalam pengelolaan uang yang masuk. Setelah itu uang dan laporannya diserahkan kepada bendahara.

Dalam pembukuan keuangan, setiap uang yang keluar maupun masuk, dicatat oleh bendahara. Serta setiap orang yang bertransaksi dengan bendahara wajib memberikan tanda tangan di setiap kali transaksinya. Setelah itu catatan keuangan tersebut dilaporkan setiap kali warga mengadakan pertemuan. Hal ini dilakukan demi terciptanya sistem yang transparan, kewajiban memberikan tanda tangan sebagai tanda bukti penerimaan yang sah. Dalam sistem administrasi dan keuangan, pengelola rumah dome telah berhasil membuat sistem yang transparan. Sehingga semua warga tahu dan paham serta tidak menimbulkan curiga dan iri hati.

Selain itu pengelola memberikan kebebasan kepada Pokdarwis dalam mengelola kegiatan wisata. Sehingga Pokdarwis aktif dalam mengajukan program pengembangan desa wisata kepada pengelola rumah dome, seperti pengajuan dana pembuatan video profil desa wisata untuk persyaratan lomba desa wisata.

Dampak Pengembangan Desa Wisata Rumah Dome

Pengelolaan rumah dome membawa dampak yang cukup baik bagi masyarakat lokal. Diantara dampak yang mulai dirasakan warga akan dijelaskan sebagai berikut :

\section{Aspek Ekonomi.}

Timbulnya Lapangan Pekerjaan Baru.

Warga yang dulunya mendapatkan pemasukan dari bertani, secara perlahanlahan dapat merasakan manfaat tambahan dari adanya kegiatan wisata di kehidupan mereka. Manfaat berupa munculnya lapangan pekerjaan baru sebagai petugas pelaksana harian kegiatan wisata. Seperti menjadi pemandu outbond, pemandu wisata, petugas parkir, petugas keamanan, petugas tiket, petugas kebersihan. Dalam hal pemberian uang jasa, pengelola bersama warga mendiskusikan dan memutuskan berapa besarannya. Meski hasil pendapatan dari pekerjaan tersebut tergolong kecil, warga optimis akan mendapatkan hasil yang lebih baik, seiring kemajuan desa wisata rumah dome. Rasa percaya warga kepada pengelola justru muncul karena uang jasa dibuat berdasarkan keputusan musyawarah bersama, sehingga sistemnya transparan.

\section{Meningkatkan Pendapatan Warga} Setempat.

Pada awal warga direlokasi ke komplek rumah dome, pemerintah kabupaten Sleman yang membayar biaya sewa tanah selama kurang lebih 3 tahun kepada pemerintah desa Sumberharjo. Setelah itu warga melakukan iuran untuk membayar biaya sewa tanah sesuai luas tanah masingmasing yang dulu diberikan oleh pihak pemerintah desa (Aman, Wawancara).

Pada awal berdirinya desa wisata rumah dome, pengelola memberikan uang kepada setiap warga sebesar Rp 20.000 per 3 bulan sekali dari pemasukan desa wisata. Berawal dari inilah pengelola bertekad untuk bisa membayarkan sewa tanah warga kepada pemerintah desa Sumberharjo.

Seiring berjalannya waktu, kondisi desa wisata rumah dome pun berkembang. Pendapatan dan sistem pengelolaan keuangan juga meningkat. $20 \%$ dari pendapatan bersih desa wisata rumah dome adalah uang milik warga yang diwujudkan dalam bentuk kas desa. Warga telah sepakat bahwa uang kas tersebut digunakan untuk membayar biaya sewa 
tanah pertahun kepada pemerintah desa Sumberharjo. Sudah 3 tahun terakhir sejak 2014, warga tidak perlu melakukan iuran untuk membayar biaya sewa tanah kepada pemerintah desa Sumberharjo.

\section{Memunculkan Dana Pengembangan Masyarakat.}

Warga menyadari bahwa mereka harus mengalokasikan uang untuk pengadaan dan perawatan fasilitas wisata. Oleh karena itu mereka mengganggarkan dana pengembangan fasilitas wisata sebesar $20 \%$ dari $100 \%$ pendapatan bersih pemasukan desa wisata. Dana ini digunakan untuk pengembangan spot foto, pengadaan dan perawatan fasilitas paket wisata. Selain itu komitmen warga untuk mengembangkan potensi daya tarik wisatanya cukup tinggi. Hal ini dapat dilihat dengan keputusan warga untuk menggunakan program pemerintah, yaitu dana desa untuk pengembangan bukit teletabis.

Pada sekitar bulan April 2017, warga sepakat memangkas semua pohon di area komplek rumah dome yang tingginya melebihi rumah dome demi memenuhi syarat pencairan dana pengembangan bukit Teletabis. Setelah pemangkasan pohon, warga tersadar dengan kondisi tampilan rumah dome yang kotor, retak dan lumutan. Hal ini menyebabkan warga berinisiatif melakukan pengecatan ulang rumah dome. Sehingga ketika wisatawan datang ke desa wisata atau bukit Teletabis, pemandangan rumah dome pun menjadi terkesan lebih berwarna, segar dan menarik. Warga memusyawarahkan pembiayaan pengecatan seluruh rumah dome dengan menggunakan dana yang ada.

Selain itu pengelola mencoba mengajukan potongan harga pembelian cat kepada pihak distributor dari PT Avian. Selain memberikan potongan harga, PT Avian justru berkenan memberikan alokasi anggaran dana corporate social responsibility (CSR) kepada desa wisata dengan beberapa syarat tertentu. Pengelola mengajukan pengecatan ulang karena pengecatan yang pertama masih kurang dan dana untuk kegiatan tahunan yaitu merti dusun. Sedangkan PT Avian akan menggunakan desa wisata rumah dome sebagai bahan promosi.

\section{Aspek Sosial \\ Peningkatan Kualitas Hidup.}

Pada awalnya warga masih belum yakin jika desa wisata rumah dome dapat membantu perekonomian mereka, karena lokasinya yang terpencil dan dikelilingi pohon tebu. Akan tetapi pengelola optimis bahwa desa wisata rumah dome akan terus berkembang sehingga dapat memberikan harapan kepada warga secara perlahan. Demi mewujdkan harapan tersebut, pengelolaan desa wisata rumah dome berubah dan perlahan berkembang dengan menawarkan paket-paket wisata. Terlebih lagi, pengelola menaikkan tarif harga paket wisata setiap tahunnya demi mencukupi kebutuhan warga dan untuk pengembangan desa wisata rumah dome.

Kondisi desa wisata rumah dome yang semakin ramai pun telah memicu warga untuk mencoba mengolah hasil bumi agar memiliki daya jual yang tinggi. Warga yang bermata pencaharian sebagai petani dan bertani dijadikan sebagai tumpuan ekonomi, telah berani mencoba mendapatkan tambahan pendapatan dengan cara berjualan. Ibu-ibu yang biasanya membantu suami bertani di sawah, sekarang telah bisa berjualan dengan membentuk UKM yang didampingi oleh sebuah LSM. Melalui LSM inilah warga belajar mengolah makanan dan dibantu dalam pembuatan PIRT sebagai upaya legalitas hasil olahan makanan yang mereka jual. Misalnya bonggol pisang diolah menjadi stik bonggol pisang, lempeng. Dulu mereka hanya menjual garut dalam bentuk mentah dengan harga per kg nya adalah Rp 2.500. Sekarang mereka mengolah garut, menjadi emping garut dengan kisaran 65-75 ribu per kg. Warga pun mulai membuka toko kelontong setelah desa wisata rumah dome mulai ramai dikunjungi.

Peningkatan Kebanggaan Komunitas.

Desa wisata rumah dome pernah meraih prestasi cukup membanggakan yaitu juara harapan 3 pembuatan video profil desa wisata se DIY tahun 2015 dan juara favorit pada tahun 2016 ("Bantul Bakal Beri Dana 
Stimulus, Sleman Jajal Desa Wisata dengan Festival," 2016).

Desa wisata rumah dome sudah masuk dalam klasifikasi desa wisata mandiri. Pengelola berharap, setelah desa wisata ini mengadakan pengecatan ulang, kondisi desa wisata ini pun semakin ramai dikunjungi wisatawan. Selain itu, salah satu bentuk ekspresi kebanggaan warga sebagai penduduk desa wisata rumah dome, adalah dengan memodifikasi acara tahunan merti dusun dengan konsep baru dan segar. Selain itu, pengelola melibatkan pihak UKM dome dan UKM dari luar dome dalam acara ini. Pada awalnya, tujuan utama acara merti dusun adalah sebagai rasa syukur kepada Tuhan. Akan tetapi, pengelola juga memanfaatkan acara tersebut sebagai media promosi potensi desa wisata rumah dome dan mengenalkan produk makanan khas hasil olahan dari daerah masing-masing ("Rumah Domes Gelar Festival Budaya," 2017).

\section{Memicu Pembagian Peran yang Adil.}

Hampir setiap elemen warga dusun New Nglepen memiliki perannya masingmasing dalam pengelolaan dan pengembangan desa wisata rumah dome. Mulai dari peran dari kepala kepada dusun, RT, RW, tokoh dusun, ketua blok, bapakbapak, ibu-ibu hingga pemuda. Semua terlibat dalam dalam kepengurusan rumah dome dan beberapa dari mereka menjabat sebagai petugas bendahara, sekertaris, Pokdarwis, seksi kebersihan, seksi LINMAS, seksi keamanan.

\section{Membangun Manajemen Organisasi Warga.}

Pemicu awal berkembangnya rumah dome adalah banyaknya kunjungan tamu untuk melihat komplek rumah dome, baik sebelum peresmian atau sesudah peresmian. Awalnya warga berinisiatif mengelola retribusi parkir. Setelah itu dibentuklah sebuah kepengurusan, sehingga apabila ada tamu yang datang, pihak warga ada yang menyambutnya. Selain itu dalam hal keuangan, agar ada laporan keuangan kepada warga.

Desa wisata rumah dome pun berbadan hukum BUMDes dan resmi didaftarkan sebagai desa wisata oleh dinas pariwisata kabupaten Sleman. Pengelola rumah dome pun sudah memiliki SK dari pemerintah desa sejak 2015 dan Pokdarwis memiliki SK dari dinas pariwisata kabupaten Sleman. Dalam kepengurusan, kepala desa Sumberharjo menjabat sebagai pelindung, kepala dusun sebagai penasehat, lalu turun ke ketua 1 dan 2 pengelola rumah dome dan ke seksi-seksinya.

Dalam pembagian pendapatan, warga menyepakati bahwa pendapatan dibagi atas dasar persen (\%). Dari pendapatan total, dikurangi uang makan perhari bagi petugas pelaksana harian (Pokdarwis). Setelah itu dibagi $45 \%$ untuk Pokdarwis digunakan untuk membayar petugas harian. 20\% untuk warga digunakan untuk membayar biaya sewa tanah pertahun. $20 \%$ untuk kas dan pengembangan digunakan untuk pengadaan dan perawatan fasilitas wisata dan $15 \%$ untuk pengelola. Pengelola juga membentuk 3 bendahara untuk mengurus masing-masing keuangan, bendahara utama yang juga menangani honor pengelola (15\%), bendahara yang menangani keuangan warga $(20 \%)$ dan bendahara kas pengembangan (20\%).

\section{Aspek Budaya \\ Mendorong Warga Menghormati Budaya Lain.}

Pada dasarnya warga dusun New Nglepen mayoritasnya adalah petani. Akan tetapi mereka mau memanfaatkan peluang yang ada, dengan bersedia belajar hal baru yaitu pariwisata. Agar desa wisata rumah dome semakin layak untuk dikunjungi wisatawan, warga belajar sebuah kebiasaan baru. Kebiasaan baru tersebut adalah SAPTA PESONA, dan warga diminta untuk menerapkannya dalam kehidupan sehari-hari. Sehinga jika mereka bertemu dengan wisatawan yang, warga harus bersikap ramah dan sopan. Sehingga akan tercipta kegiatan wisata.

Mendorong Pertukaran Budaya.

Bahasa jawa adalah bahasa ibu bagi warga dusun New Nglepen. Mereka menggunakan bahasa jawa dalam kehidupan sehari-hari. Akan tetapi karena mayoritas wisatawan menggunakan bahasa indonesia, maka warga sedikit demi sedikit belajar menggunakan bahasa indonesia. Sehingga warga bisa berinteraksi dengan banyaknya wisatawan yang berkunjung. 
Selain itu, warga bercerita kepada wisatawan bahwa komplek rumah dome pada awalnya digunakan untuk merelokasi korban gempa tahun 2006. Warga yang mayoritasnya petani justru tidak menyangka akan menjadi sebuah desa wisata. Dari cerita tersebut wisatawan menjadi tahu mengenai cara hidup warga desa wisata rumah dome (the way of life). Sehingga wisatawan mengetahui alasan penambahan bangunan semi permanen ataupun permanen di dalam komplek rumah dome adalah karena memang kebutuhan para penduduk yang mayoritasnya petani, yang butuh tambahan tempat untuk menyimpan hasil panen.

Beberapa wisatawan yang datang berkunjung justru mengajak pengelola untuk berdiskusi mengenai pengelolaan desa wisata. Terkadang beberapa orang wisatawan adalah pengelola desa wisata dari daerah lain seperti dari Jepara, NTB, Solok. Mereka datang berkunjung untuk belajar pengelolaan desa wisata rumah dome. Dari diskusi tersebut, timbulah saling tukar ide, masalah dan solusi. Secara tidak langsung, wawasan pengelola rumah dome justru bertambah karena hal ini (Sulasmono, Wawancara).

\section{Menanamkan Pengembangan Budaya Lokal.}

Turonggo Mudo Sakti Manunggal adalah organisasi kesenian jathilan gabungan dari desa wisata rumah dome dengan dusun di sebelahnya, yaitu dusun Dinginan. Upaya penggabungan ini karena desa wisata rumah dome masih minim dengan fasilitas untuk kesenian ini, baik dari peralatan maupun pelatihnya. Selain itu pengelola mencoba menghidupkan kembali kesenian tari dengan merekrut anak-anak sebagai pelaku utamanya. Akan tetapi karena usaha ini baru saja dicetuskan, banyak anak-anak yang belum berminat untuk ikut dalam organisasi kesenian tari ini.

\section{Aspek Politik}

\section{Mengaktifkan Partisipasi Warga}

Sejak awal, warga mengikuti perubahan komplek rumah dome menjadi desa wisata. Saat akan mengadakan pertemuan, pengelola memberikan undangan rapat. Warga pun memberi respon positif dengan menghadiri undangan rapat. Kemampuan pengurus yang telah terlibat juga semakin handal karena menjadi terbiasa dengan sistem administrasi yang semakin baik. Selain itu, dalam pengambilan keputusan pun, pengelola juga meminta saran dari beberapa tokoh di desa wisata rumah dome.

Di desa wisata rumah dome, pelibatan warga dalam hal fisik tergantung dari besar atau kecilnya suatu agenda wisata. Jika kegiatan tersebut memerlukan banyak tenaga, maka Pokdarwis akan meminta pengelola untuk mengajak warga bergotong royong. Jika kegiatan tersebut kecil, maka cukup anggota Pokdarwis yang menanganinya. Selain itu, bentuk partisipasi tidak langsung bagi lansia dan warga yang tidak ditunjuk dalam event adalah menghadiri acara yang diselenggarakan oleh warga. Pokdarwis adalah ujung tombak dalam kegiatan wisata di desa wisata rumah dome. Merekalah yang berinteraksi langsung dengan wisatawan, maka dari itu hampir semua anggota Pokdarwis diikutkan dalam pelatihan memandu wisata yang diadakan seminggu sekali.

\section{Meningkatkan Kekuasaan Warga Atas} Luar (Investor)

Komplek rumah dome sempat akan dijadikan objek wisata oleh investor. Akan tetapi karena bersinggungan dengan warga, dan harus terlalu memaksakan kehendak pariwisata, maka warga menolaknya. Warga yang dulu tinggal di lereng gunung kemudian harus diatur sedemikian rupa, jelas tidak bisa menerimanya. Warga khawatir jika sudah terikat perjanjian, maka harus mau diatur sedemikian rupa sehingga tidak bisa menolaknya. Terlebih lagi mereka tidak akan bisa mendapatkan pemasukannya secara penuh. Selain itu warga mengkhawatirkan bahwa tenaga kerjanya bukan berasal dari warga dusun New Nglepen. Karena mempertimbangkan hal tersebut, warga menolak tawaran pihak Kids Fun yang mencoba membeli asset di komplek rumah dome. Warga memilih untuk mengelola komplek rumah dome secara mandiri. Karena jika mereka mengelola sendiri, $100 \%$ pendapatan bisa masuk untuk desa wisata dan tenaga 
kerjanya pun juga dapat mengambil dari warga dusun New Nglepen.

Pada saat proses perubahan dari komplek rumah dome menjadi sebuah desa wisata. Pengelola meyadari bahwa mereka tidak mengetahui tentang pariwisata. Oleh karena itu muncul inisiatif bahwa mereka harus mengundang pihak terkait untuk memberikan pemahaman dan pelatihan mengenai pariwisata, khususnya tentang desa wisata.

Pada waktu itu pengelola mengikuti anjuran dari kepala desa untuk belajar ke salah satu desa wisata di Sleman. Desa wisata yang dirujuk pada waktu itu adalah Pentingsari. Dari Pentingsari inilah pengelola belajar pengelolaan desa wisata. Hal ini bertujuan agar masyarakat komplek rumah dome menjadi masyarakat yang sadar wisata.

\section{Menjamin Hak Manusia Dalam Pengelolaan Sumber Daya Alam}

Desa wisata rumah dome telah memicu kemauan warga untuk belajar mengelola sumber daya alam yang ada di lingkungan sekitar mereka. Mulai dari keterlibatan setiap elemen warga dalam pengelolaan desa wisata baik penduduk yang menetap di rumah dome atau memilih menyerahkan rumahnya kepada pengelola. Warga yang merasa tidak cocok tinggal di komplek rumah dome pun boleh meninggalkan rumah dome. Akan tetapi rumah tersebut harus diserahkan pada pengelola untuk kepengurusannya, agar tetap terpelihara dan dapat digunakan sebagai homestay. Sehingga pengelola dapat mempertanggung jawabkan kepada pemerintah desa Sumberharjo. Pengelola juga memberikan informasi terbaru mengenai desa wisata rumah dome kepada warga yang memilih tinggal diluar komplek rumah dome. Misalnya program penebangan pohon, pengecatan, kerja bakti, pembenahan lapangan.

\section{Aspek Lingkungan}

Pengembangan Daya Dukung Daerah (Carrying Capacity)

Pada dasarnya tanah yang ditinggali oleh warga adalah tanah kas desa Sumberharjo. Sehingga tidak dapat dijual-belikan dan warga hanya memiliki hak guna bangunan saja. Demi menjaga kenyamanan, kemanan dan ketertiban, warga telah menyepakati aturan untuk tinggal di komplek rumah dome yang dibuat bersama. Beberapa aturan diantaranya adalah, rumah dome hanya boleh ditinggali oleh pemilik atau keluarganya. Serta tidak boleh dijual, tidak boleh dipindah tangankan atau disewakan secara pribadi. Hewan ternak tidak diperbolehkan masuk komplek rumah dome. Untuk unggas seperti ayam, masih bisa ditolerir dengan cara dikurung. Beberapa aturan tersebut ternyata berdampak baik bagi kegiatan wisata di desa wisata rumah dome. Karena aturan tersebut kebersihan dan kenyamanan di desa wisata pun tetap terjaga. Selain itu, pengelola rumah dome telah menyewa lapangan yang berada disebelah selatan komplek rumah dome. Untuk kedepannya, lapangan ini akan difungsikan sebagai sarana kegiatan outbond wisatawan dan acara tahunan merti dusun.

\section{Meningkatkan Kesadaran Pengelolaan Pembuangan Limbah}

Selain warga harus mengurusi sampah rumah tangga, akibat banyaknya wisatawan yang berkunjung pun juga membawa dampak negatif, yaitu sampah. Pada awalnya sampah hanya di letakkan begitu saja di dekat kandang komunal milik warga, akan tetapi lama-lama tempat penampungan sampah sementara tersebut penuh. Oleh sebab itu pengelola mencoba membuat gudang sampah dengan memanfaatkan bangunan yang terbengkalai yang berada di samping lapangan. Akan tetapi kepala desa tidak mengijinkan jika tanah kas desa dibangun bangunan permanen, kecuali harus ijin ke Gubernur. Setelah cara kedua gagal, pengelola justru mendapat usulan dari salah satu warga yaitu Bp Surat untuk mengumpulkan sampah dirumah miliknya, karena beliau ingin mengembangkan pengelolaan sampah. Setelah mendapat tawaran tersebut, warga memilah sampah basah dan kering sebelum dikirim ke Bp Surat agar sampah-sampah tersebut dapat dijadikan kompos.

Meningkatkan Kesadaran Akan Perlunya Konservasi

Beberapa aturan yang disusun dan disepakati bersama pada tahun 2013 oleh 
warga, justru telah mempertahankan komplek rumah dome baik dari segi bangunan maupun lingkungan. Untuk menjaga keamanan warga, warga membuat portalisasi, mengacu pada perizinan portalisasi dari desa Sumberharjo. Selain itu, untuk menjaga kebersihan dan keindahan komplek dome akan dilaksanakan kerja bakti masal, untuk hari, tanggal dan waktu pelaksanaannya akan ditentukan oleh pengurus rumah dome. Pengelola rumah dome juga dengan tegas melarang warga untuk memberikan akses kepada orang lain, kecuali keluarganya untuk menghuni rumah dome. Karena dikhawatirkan akan merusak tatanan yang ada dan sudah berlaku.

\section{PENUTUP}

Konsep Community Based Tourism (CBT) merupakan solusi jitu dalam mengatasi segala tantangan pengembangan desa wisata agar tercapai pengelolaan desa wisata yang berkelanjutan. Implementasi konsep CBT memiliki tantangan yang sulit dalam hal mewujudkan partisipasi masyarakat.

Tinjauan berdasarkan teori partisipasi, partisipasi masyarakat dalam pengelolaan Desa Wisata Rumah Dome melewati tahap-tahap berikut : Tahap manipulasi, terapi, menyampaikan informasi, konsultasi, torkenism, peredaman kemarahan, kekuasaan masyarakat, kemitraan, pendelegasian kekuasaan dan saat ini sampai pada tahap pengawasan masyarakat.

Walaupun pengelolaan desa wisata rumah dome belum sepenuhnya merefleksikan pengelolaan CBT, karena kepemilikan tanah dan rumah di Dusun Nglepen bukan milik warga setempat melainkan milik pemerintah desa.

Akan tetapi, masyarakat telah memiliki rasa memiliki dan kepedulian yang tinggi terhadap Desa Wisata Rumah Dome dikarenakan dampak positif yang mereka rasakan melalui pengembangan desa wisata. Walaupun, pada awalnya kehidupan sosial budaya masyarakat di Kampung Nglepen Baru membutuhkan adaptasi sosio kultural yang sulit.
Semakin tinggi partisipasi warga, maka akan semakin tinggi dampak perkembangan bagi masyarakat. Selanjutnya dampak positif yang dirasakan cenderung mempengaruhi tingkat partisipasi masyarakat dalam pengembangan pariwisata.

Artikel ini merekomendasikan untuk meningkatkan partisipasi warga melalui cara yang lebih persuasif dan edukatif. Pengelola perlu merumuskan berbagai upaya dan regulasi untuk memaksimalkan dampak posistif yang mampu dirasakan warga secara nyata. Karena dampak positif yang dirasakan merupakan merupakan motivasi masyarakat lokal untuk berpartisipasi dalam pengembangan desa wisata agar tercapai community based tourism serta pengelolaan pariwisata yang berkelanjutan.

\section{REFERENSI}

Ayuningtyas, K. (2016). New Ngelepen Kampung Teletubbies Pasca Gempa Yogya. Retrieved November 9, 2017, from http://www.benarnews.org

Bantul Bakal Beri Dana Stimulus, Sleman Jajal Desa Wisata dengan Festival. (2016). Retrieved November 23, 2016, from https://gudeg.net

Creswell, J. W. (1994). Research DesignQualitative, Quantitative, and Mixed Method. London: SAGE Publications.

Eko Anton Rubiantoro dan Ragil Haryanto. 2013. Bentuk Keterlibatan Masyarakat dalam Upaya Penghijauan pada Kawasan Hunian Padat di Kelurahan Serengan - Kota Surakarta. Biro penerbit Planologi Undip. Volume 9 (4) : 416-428 Desember 2013.

Farmer, B. (1993). Needs and Means. (Ben Farmer dan Hentie Low, Ed.). London: Routledge.

Hermawan, H. (2016a). Dampak Pengembangan Desa Wisata Nglanggeran Terhadap Ekonomi Masyarakat Lokal. Jurnal Pariwisata, 3(2), 105-117.

Hermawan, H. (2016b). Dampak Pengembangan Desa Wisatanglanggeran Terhadap Sosial 
Budaya Masyarakat Lokal. In Seminar Nasional Ilmu Pengetahuan dan Komputer (SNIPTEK) Nusa Mandiri (pp. 426-435). Bandung Indonesia: SNIPTEK 2016. Retrieved from

http://konferensi.nusamandiri.ac.id/pr osiding/index.php/sniptek/issue/view/ $1 \% 0 \mathrm{~A}$

Hermawan, H. (2017). Pengaruh Daya Tarik Wisata, Keselamatan dan Sarana Wisata Terhadap Kepuasan serta Dampaknya terhadap Loyalitas Wisatawan : Studi Community Based Tourism di Gunung Api Purba Nglanggeran. Wahana Informasi Pariwisata: Media Wisata, 15(1), 562-577.

Hermawan, H. (2017). Pengembangan Destinasi Wisata pada Tingkat Tapak Lahan dengan Pendekatan Analisis SWOT. Jurnal Pariwisata, 4(2), 64 74.

Hermawan, H. (2017). Strategi Pengembangan Kampung Batu Malakasari sebagai Daya Tarik Wisata Minat Khusus. Retrieved https://scholar.google.co.id/citati ons? user=OP19i9oAAAAJ \&hl=i d

Kyrgyz Community Based Tourism. (2017). Retrieved from www.cbtkyrgyztan.kg

Martono. (2013). Mengenang Gempa Tektonik 2006 di Yogyakarta dan Sekitarnya 27 Mei 2013. Retrieved January 7, 2017, from http://www.kompasiana.com/jk.marto no/mengenang-gempa-tektonik-2006di-yogyakarta-dan-sekitarnya

Moleong, L. (1995). Metode penelitian. Bandung: Remaja Rosda Karya.

Muktaf, Z. M. (2017). Wisata Bencana: Sebuah Studi Kasus Lava Tour Gunung Merapi. Jurnal Pariwisata, 4(2), 84-93.

Nuryanti, W. (1993). Concept, Perspective and Challenges. Makalah Bagian Dari Laporan Konferensi Internasional Mengenai Pariwisata Budaya, 2-3.

Pitana, I. (2009). Pengantar Ilmu Pariwisata. Yogyakarta: andi.
Rumah Domes Gelar Festival Budaya. (2017). Retrieved June 18, 2017, from

http://sinarharapan.net/2017/06/ruma h-domes-gelar-festival-budaya

Saraswati, T. (2008). Kontroversi Rumah Dome di Nglepen, Prambanan, D.I. Yogyakarta. DIMENSI (Journal of Architecture and Built Environment), 35(2), pp-136.

Sherry R. Arnstein .1969. A Ladder Of Citizen Participation. Journal of the American Institute of Planners 35:4 2016, 216-224, DOI $: 10.1080 / 019443669089 / / 225$

Suansri, P., Yeejaw-haw, S., \& Richards, P. (2013). CBT standard handbook. Chiang Mai: The Thailand Community-Based Tourism Institute.

Sugiyono. 2011. Metode Penelitian Kuantitatif Kualitatif dan $R \& D$. Cetakan ke 14. Bandung: Alfabeta.

Sunaryo, B. (2013). Kebijakan Pembangunan Destinasi Pariwisata: Konsep dan Aplikasinya di Indonesia. Penerbit Gava Media.

Victoria br. Simanungkalit, Destry Anna Sari, Frans Teguh, Hari Ristanto, Ika K, Leonardo Sambodo, Samsul Widodo, Masyhud, Sri Wahyuni, Henky Hermantoro, Henky Hermantoro, D. V. (2015). Buku Panduan Pengembangan Desa Wisata Hijau. (C. Novianti, Ed.). Jakarta: Asisten Deputi Urusan Ketenagalistrikan dan Aneka Usaha Kementerian Koperasi dan UKM Republik Indonesia.

\section{BIODATA PENULIS}

Dhimas Setyo Nugroho S.Par., M.M., adalah dosen muda di AKPAR BSI Yogyakarta. Pendidikan S1 di selesaikan di STP AMPTA Yogyakarta. Pendidikan S2 diselesaikan di Universitas Sarjanawiyata Tamansiswa Yogyakarta. 